\title{
Sjónskerðing og blinda Reykvíkinga 50 ára og eldri \\ Reykjavíkuraugnrannsóknin
}

Elín Gunnlaugsdóttir'1,2, læknir, Ársæll Már Arnarsson ${ }^{1,3}$, lifeðlisfræðingur, Friðbert Jónassonn ${ }^{1,2}$, læknir

\section{ÁGRIP}

Inngangur: Tilgangur rannsóknarinnar var að kanna algengi, 5 ára nýgengi og orsakir sjónskerðingar og blindu miðaldra og eldri Reykvíkinga.

Efniviður og aðferðir: Pátt tóku 1045 einstaklingar sem allir voru 50 ára eða eldri og valdir með slembiúrtaki úr Pjóðskrá. Pátttakendur gengust undir nákvæma augnskoðun árið 1996 og 5 árum síðar var hún endurtekin hjá 846 sem pá voru á lífi. Sjónskerðing var skilgreind samkvæmt flokkun Alpjóðaheilbrigðismálastofnunarinnar (WHO) sem besta-sjónskerpa (með sjónglerjum ef pörf var á) á bilinu $3 / 60$ til $<6 / 18$ eða sjónsvið sem nemur $\geq 5^{\circ}$ en $<10^{\circ}$ umhverfis miðjupunkt. Sjónskerpa sem nemur minna en 3/60 telst til blindu. Könnuð var orsök sjóntapsins í öllum augum sem reyndust vera sjónskert eða blind.

Niðurstöður: Algengi sjónskerðingar var 1,0\% (95\% öryggismörk 0,4-1,6) og blindu 0,6\% (95\% öryggismörk 0,1-1,0). Fimm ára nýgengi sjónskerðingar var 1,1\% (95\% öryggismörk 0,4-1,8) og blindu 0,4\% (95\% öryggismörk 0,0-0,8). Algengi sjónskerðingar meðal 60-69 ára pátttakenda var 0,6\% en jókst upp í 7,9\% pegar skoðaðir voru pátttakendur sem voru orðnir áttræðir eða eldri. Aldursbundin hrörnun í augnbotnum var helsta orsök sjóntaps, bæði við upphafs- og eftirfylgdarskoðun. Skýmyndun á augasteini var aðalorsök vægari sjónskerðingar. Helstu orsakir sjóntaps sem einskorðaðist við aðeins eitt auga voru latt auga og skýmyndun á augasteini.

Ályktun: Algengi og 5 ára nýgengi sjónskerðingar og blindu eykst með aldri. Aldursbundin hrörnun í augnbotnum var helsta orsök alvarlegs sjóntaps en skýmyndun á augasteini var algeng orsök vægari sjónskerðingar.

Tímaritið Acta Ophthalmologica hefur gefið leyfi sitt fyrir tvíbirtingu pessa efnis. Pað var birt áđur í tveimur greinum:

Gunnlaugsdottir E, Arnarsson A, Jonasson F. Prevalence and causes of visual impairment and blindness in Icelanders aged 50 years and older: the Reykjavík Eye Study. Acta Ophthalmol 2008; 86: 778-85.

Gunnlaugsdottir E, Arnarsson A, Jonasson F. Five-year incidence of visual impairment and blindness in older Icelanders: the Reykjavík Eye Study. Acta Ophthalmol 2010; 88; 358-66.

${ }^{1}$ Augndeild Landspítala, 2ææknadeild Háskóla Íslands, 3tilraunastofu í taugavísindum, Háskólanum á Akureyri.

Fyrirspurnir: Elín Gunnlaugsdóttir elingun@gmail.com

Greinin barst 26. nóvember 2012 , sampykkt til birtingar

30. janúar 2013.

Engin hagsmunatengs। gefin upp.

\section{Inngangur}

Um 1950 áætlaði Guðmundur Björnsson augnlæknir að um tíundi hver einstaklingur á aldrinum 80-85 ára og að minnsta kosti fjórði hver maður yfir níræðu væri blindur. Samkvæmt pví var algengi blindu á Íslandi mun hærra en tíðkaðist í Evrópu og Norður-Ameríku. Á seinni hluta áttunda áratugar síðustu aldar og fyrri hluta pess níunda fóru fram tvær rannsóknir á augnhag Íslendinga. Í Augnrannsókn Borgarness ${ }^{2}$ sem fór fram 1976-1978 rannsakaði Guðmundur Björnsson augnlæknir um 60\% bæjarbúa 40 ára og eldri og á árunum 1980 til 1984 ferðaðist Friðbert Jónasson augnlæknir um Austfirði og skoðaði yfir 80\% íbúa 43 ára og eldri á Eskifirði, Reyðarfirði og í Neskaupstað. ${ }^{3}$ Algengi blindu í pessum hópum var áætlað $2 \%$ í báðum rannsóknunum. Næsta faraldsfræðilega rannsókn á augnhag Íslendinga var Reykjavíkuraugnrannsóknin sem hófst árið 1996.

Íslendingar eru langlífir og meðallífslíkur okkar við fæðingu eru 81,5 ár.4 Samkvæmt mannfjöldatölum Hagstofu Íslands ${ }^{5}$ fjölgaði Íslendingum, 50 ára og eldri, um 50\% frá 1996 til 2012 og vitað er að með hækkandi aldri eykst algengi augnsjúkdóma. ${ }^{6-8}$ Blinda er lokastig margra augnsjúkdóma og ætla má að sjónskertum og blindum Íslendingum fari fjölgandi og pörfin fyrir augnpjónustu og almenna aðhlynningu muni aukast í samræmi við pað. Alvarlegt sjóntap eykur hættuna á beinbrotum ${ }^{9}$ og kostnaður sjúkratrygginga vegna sjónskertra einstaklinga er hærri en vegna peirra sem ekki eru sjónskertir. Áætlað hefur verið að um 90\% sjúkratryggingakostnaðar sjónskertra sé ekki vegna augnpjónustu heldur annarra vandamála. ${ }^{10}$

Tilgangur pessa hluta Reykjavíkuraugnrannsóknarinnar var að afla upplýsinga um sjónskerpu miðaldra og eldri Íslendinga og kanna hvaða sjúkdómar liggja að baki alvarlegri sjónskerðingu og blindu. Hlutar af niðurstöðum rannsóknarinnar hafa birst áður. ${ }^{12,13} \mathrm{Meg}$ inniðurstöðurnar úr peim greinum eru dregnar fram hér pví upplýsingar af pessu tagi eru mikilvægar pegar skipuleggja skal forvarnir og áætla hversu umfangsmikla heilbrigðispjónustu pessir einstaklingar koma til með að purfa.

\section{Efniviður og aðferðir}

Reykjavíkuraugnrannsóknin fór fram í september og október 1996. Fimm árum síðar, í september og október árið 2001, voru pátttakendur sem enn voru á lífi kallaðir í eftirfylgdarskoðun. Pátttakendur voru valdir með slembiúrtaki úr Pjóðskrá yfir Reykvíkinga 50 ára og eldri og samanstóð úrtakið af 6,4\% pýðisins fyrir hvert fæðingarár og bæði kyn. Af peim 1635 sem safnað var, náðist til 1379 og völdu 1045 að taka pátt í rannsókninni árið 1996. Við eftirfylgd árið 2001 höfðu 86 einstaklingar látist $(8,2 \%)$ og $846(88,2 \%)$ eftirlifendur kusu að taka pátt. Allir pátttakendur gengust undir augnskoðun 
Mynd 1. Orsakir sjónskerđingar. Úrvinnsla byggð á fjölda einstaklinga með sjónskerđingu í bádum augum (10 einstaklingar, 20 augu).

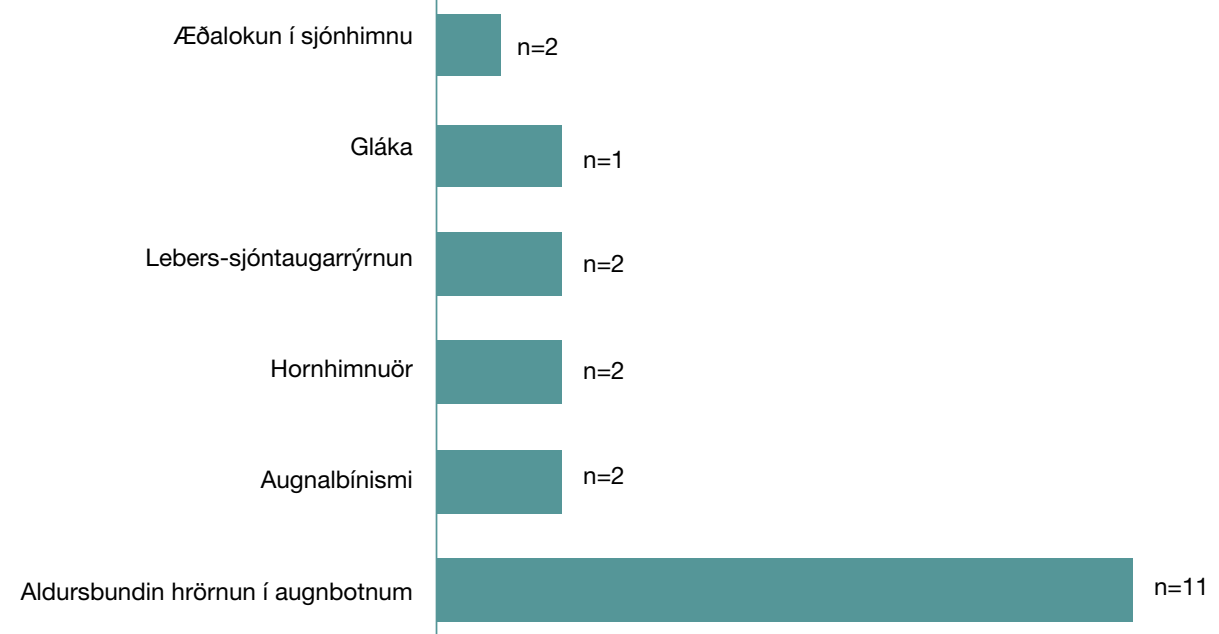

auk pess að svara spurningalista um almennt heilsufar, lífsvenjur, augnheilsu, lyfjanotkun og fyrri augnskurðaðgerðir.

Fengið var sampykki Tölvunefndar og Siðanefndar fyrir rannsókninni.

Augnskoðunin fólst meðal annars í mati á sjónskerpu í hvoru auga fyrir sig með Snellen-sjónmælingatöflu í 6 metra fjarlægð. Ef pátttakendur sáu ekki neðstu línu á kortinu (samsvarandi 6/6 í sjónskerpu) var besta-sjónskerpa metin með aðstoð sjónglerja. Ef einstaklingur gat ekki greint neinn bókstaf á Snellen-töflunni, pað er ef sjónskerpa var verri en 6/60, var fjarlægðin minnkuð í prjá metra, síðan tvo og að lokum einn metra. Ef enn var ekki hægt að meta sjónskerpu var kannað hvort pátttakandi gæti talið fingur, metið handarhreyfingu eða skynjað ljós í eins eða hálfs metra fjarlægð. Aðrir pættir augnskoðunarinnar fólust meðal annars í rauflampaskoðun sem gerð var af augnlækni, Scheimpflug-sneiðmyndatöku (Nidek EAS 1000; Nidek Co. Ltd, Gamagori, Japan) af augasteini og fremri hluta augans, ásamt prívíddarmyndatöku af sjóntaug og augnbotni (Nidek 3Dx/NM; Nidek Co. Ltd, Gamagori, Japan). Sjónsviðsmæling var gerð (Octopus G1X; Interzeag AG, Schilieren, Sviss) ef pátttakandi hafði sögu um gláku eða ef útlit sjóntaugar vakti grun um sjúkdóminn.

Tafla I. Algengi (\%) og 5 ára nýgengi sjónskerðingar og blindu samkvæmt skilgreiningu Albjóðaheilbrigðismálastofnunarinnar. Fjöldi = fjöldi pátttakenda; $n=$ fjöldi einstaklinga með sjónskerðingu eða blindu; 95\% Cl = 95\% öryggismörk.

\begin{tabular}{ccccc|cccc} 
& \multicolumn{4}{c}{ Sjónskerðing - algengi } & \multicolumn{3}{c}{ Sjónskerðing - 5 ára nýgengi } \\
\hline Aldur & Fjöldi & $\mathrm{n}$ & $\%$ & $95 \% \mathrm{Cl}$ & Fjöldi & $\mathrm{n}$ & $\%$ & $95 \% \mathrm{Cl}$ \\
\hline $50-59$ & 360 & 0 & 0 & - & 303 & 0 & 0 & - \\
\hline $60-69$ & 355 & 2 & 0,6 & $0,0-1,4$ & 301 & 2 & 0,7 & $0,0-1,6$ \\
\hline $70-79$ & 254 & 2 & 0,8 & $0,0-1,9$ & 203 & 5 & 2,5 & $0,3-4,6$ \\
\hline $80+$ & 76 & 6 & 7,9 & $1,7-14,1$ & 35 & 2 & 5,7 & $0,0-13,8$ \\
\hline Alls & 1045 & 10 & 1,0 & $0,4-1,6$ & 842 & 9 & 1,1 & $0,4-1,8$ \\
& & Blinda - algengi & & Blinda - 5 ára nýgengi \\
\hline Aldur & Fjöldi & $\mathrm{n}$ & $\%$ & $95 \% \mathrm{Cl}$ & Fjöldi & $\mathrm{n}$ & $\%$ & $95 \% \mathrm{Cl}$ \\
\hline $50-59$ & 360 & 0 & 0 & - & 303 & 0 & 0 & - \\
\hline $60-69$ & 355 & 0 & 0 & - & 303 & 1 & 0,3 & $0,0-1,0$ \\
\hline $70-79$ & 254 & 1 & 0,4 & $0,0-1,2$ & 204 & 1 & 0,5 & $0,0-1,5$ \\
\hline $80+$ & 76 & 5 & 6,6 & $0,9-12,3$ & 36 & 1 & 2,8 & $0,0-8,4$ \\
\hline Alls & 1045 & 6 & 0,6 & $0,1-1,0$ & 846 & 3 & 0,4 & $0,0-0,8$ \\
\hline
\end{tabular}

Stuðst er við skilgreiningar Alpjóðaheilbrigðismálastofnunarinnar (WHO) við mat á sjóntapi. ${ }^{11}$ Sjónskerðing er skilgreind sem besta-sjónskerpa (með sjónglerjum ef pörf er á) $<6 / 18$, en pó ekki verri en $3 / 60$, eða sjónsvið sem er eingöngu $5^{\circ}$ til $<10^{\circ}$ frá miðjupunkti. Besta-sjónskerpa sem er $<3 / 60$, eða sjónsvið minna en $5^{\circ}$ frá miðjupunkti flokkast sem blinda. Á Íslandi er lögblinda skilgreind sem besta-sjónskerpa $\leq 6 / 60$.

Orsök sjóntaps var metin út frá rannsóknargögnum ${ }^{12,13}$ og hefur greiningarskilmerkjum aldursbundinnar augnbotnahrörnunar ${ }^{14,15}$, gláku ${ }^{16}$, skýmyndunar á augasteini ${ }^{17,18}$ og sjónlagskvillum ${ }^{19-21}$ í Reykjavíkuraugnrannsókninni verið lýst áður. Ef pátttakandi hafði tvo eða fleiri sjúkdóma sem valdið geta sjónskerðingu mátu höfundar út frá sjúkraskrám og augnbotnamyndum hvaða sjúkdómur var líklegasta orsök sjóntapsins.

Algengi og 5 ára nýgengi var metið í 10 ára aldurshópum og notuð var lýsandi tölfræði við útreikning á 95\% öryggismörkum. Stuðst var við kí-kvaðrat próf og lógistíska aðhvarfsgreiningu við samanburð milli hópa.

\section{Niðurstöður}

Í töflu I er algengi og 5 ára nýgengi sjónskerðingar og blindu lýst î 10 ára aldurshópum.

Árið 1996 var algengi sjónskerðingar 1,0\% og blindu 0,6\%. Fimm ára nýgengi sjónskerðingar var 1,1\% og blindunýgengið var $0,4 \%$. Algengi lögblindu (sjónskerpa $\leq 6 / 60$ ) var $0,8 \%$. Eins og sjá má í töflunni eykst algengi sjóntaps gríðarlega í elstu aldurshópunum og sem dæmi má nefna að engin sjónskerðing er til staðar hjá peim sem eru 50-59 ára við upphafsskoðun en í elsta aldurshópnum hefur algengið stigið í tæp 8\%. Allir peir sem voru blindir við skoðunina 1996 voru eldri en 75 ára.

Fyrir hvert ár yfir 50 ára jukust líkur á sjónskerðingu við upphafsskoðun árið 1996 um 18\% (95\% öryggismörk 9-28\%; p<0,001) og blindulíkur um 28\% (95\% öryggismörk 13-45\%; p<0,001). Svipað mátti sjá við 5 ára eftirfylgdarskoðun par sem líkurnar á sjónskerðingu jukust um tæplega 15\% á ári eftir fimmtugt (95\% öryggismörk 6-24\%; $\mathrm{p}<0,001$ ).

Eftir leiðréttingu fyrir aldri voru meiri líkur á að einstaklingur með verri sjónskerpu en 6/12 árið 1996 hefði látist á 5 ára tímabilinu en peir sem sáu betur (hlufallslíkur-hlutfall 3,8; 95\% öryggismörk 


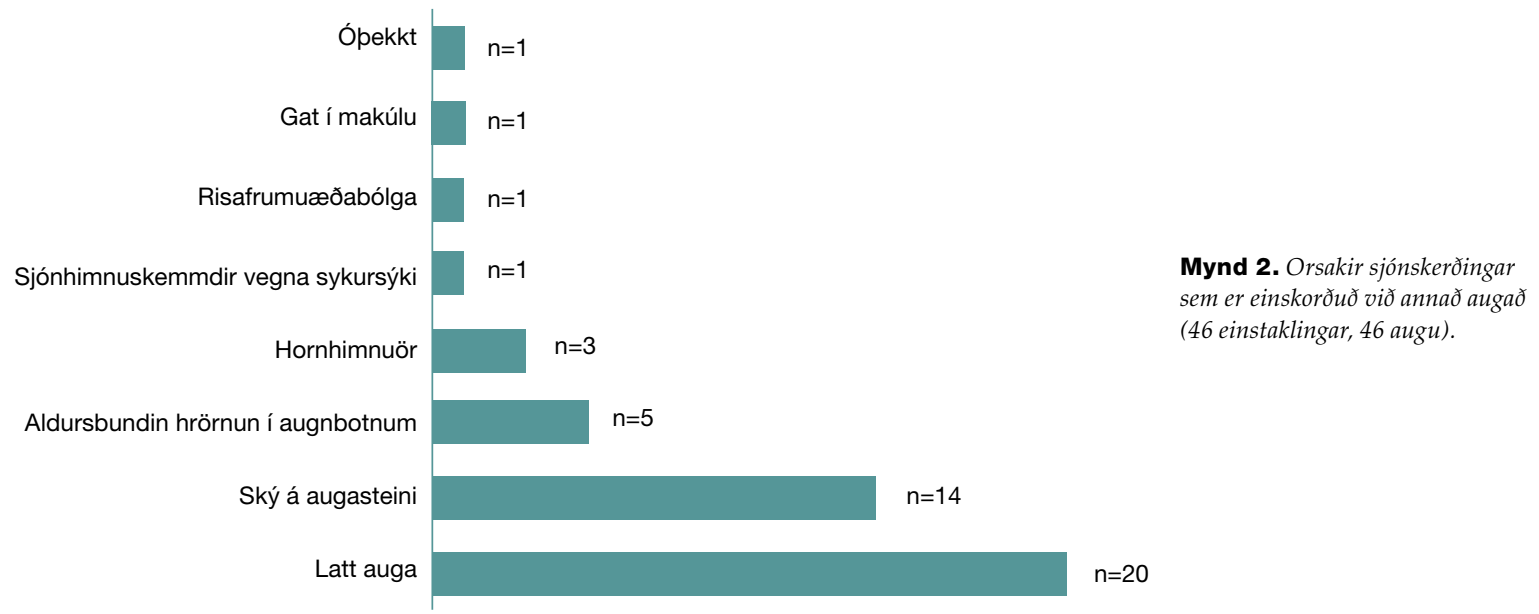

1,7-8,3; p=0,001). Tæp 80\% (eða 7 af 9) peirra sem höfðu próað með sér sjónskerðingu árið 2001 höfðu betri sjónskerpu en 6/12 árið 1996.

Árið 1996 voru alls 46 einstaklingar með sjónskerðingu sem einskorðaðist við eitt auga (4,4\% algengi; 19 hægri augu og 27 vinstri augu) og 18 manns voru blindir á aðeins öðru auganu (1,7\% algengi; 5 hægri augu og 13 vinstri augu). Fimm árum síðar höfðu 28 einstaklingar (3,5\% algengi; 17 hægri augu og 11 vinstri augu) hlotið sjónskerðingu sem bundin var við eitt auga og 10 orðið blindir (1,2\% algengi; fjögur hægri augu og 6 vinstri augu ). Við augnskoðun árið 2001 hafði sjónskerpa batnað um tvær eða fleiri Snellen-línur í báðum augum hjá 12,9\% og í öðru auganu hjá $26 \%$ pátttakenda. Um priðjungur peirra sem hlaut bætta sjón á 5 ára tímabilinu hafði farið í augasteinaskipti.

Pegar kannað var sjóntap sem var bundið við bæði augu, var aldursbundin hrörnun í augnbotnum helsta orsök bæði sjónskerðingar og blindu. Af 10 sjónskertum einstaklingum orsakaði aldursbundin augnbotnahrörnun sjónskerðinguna í báðum augum hjá 5 manns en í einu tilviki var aldursbundin augnbotnahrörnun aðalorsökin í öđru auganu en bláæðalokun í sjónhimnu í hinu auganu. Aðrar orsakir má sjá á mynd 1. Pegar einnig voru skoðaðir peir pátttakendur sem höfðu sjónskerpu á bilinu 6/18 til <6/12 mátti sjá að 38,1\% (8 einstaklingar, 16 augu) af pessu vægara formi sjónskerðingar stöfuðu af skýmyndun á augasteini. Af peim sem voru blindir á báðum augum árið 1996 olli aldursbundin augnbotnahrörnun blindunni í 5 af 6 tilvikum $(83,4 \%)$ og einn var blindur vegna bólgusjúkdóms í æða- og sjónhimnu (chorioretinitis).

Fimm árum síðar höfðu 5 einstaklingar (55,6\%) hlotið sjónskerðingu vegna aldursbundinnar augnbotnahrörnunar, prír vegna skýmyndunar á augasteini (33,3\%) og einn af völdum sjónhimnuskemmda vegna sykursýki (11,1\%). Aðeins prír einstaklingar höfðu orðið blindir, einn vegna aldursbundinnar augnbotnahrörnunar, einn vegna örs á hornhimnu og einn vegna Lebers-sjóntaugarrýrnunar.

Mynd 2 sýnir orsakir sjónskerðingar sem er aðeins bundin við annað augað. Latt auga var orsök sjónskerðingar í 43,5\% tilvika (20 augu af 46) og skýmyndun á augasteini í 30,4\% (14 augu af 46). Aldursbundin augnbotnahrörnun var sjaldgæfari orsök og olli 10,9\% (5 augu af 46) af sjónskerðingu sem aðeins var til staðar í öðru auganu. Við eftirfylgdarskoðun 5 árum síðar var skýmyndun á augasteini orsök sjóntaps í 50,0\% tilfella (14 augu) og aldursbundin augnbotnahrörnun í 32,1\% tilfella (9 augu). Aðrar sjaldgæfari orsakir sjónskerðingar í einu auga voru hornhimnusjúkdómur (bullous keratopathy; tvö augu), æðalokun í sjónhimnu (eitt auga), sjónhimnulos (eitt auga) og áverki (eitt auga).

Pegar könnuð var blinda sem var eingöngu bundin við annað augað árið 1996 var latt auga orsökin í priðjungi tilfella (6 augu af 18), gláka í 5 augum og aldursbundin augnbotnahrörnun í fjórum augum. Aðeins einn einstaklingur var blindur á öðru auga vegna áverka.

\section{Umræða}

Algengi og 5 ára nýgengi sjónskerðingar og blindu eykst með aldri. Samkvæmt okkar niðurstöðum eru bæði algengi og 5 ára nýgengi sjónskerðingar meðal 50 ára og eldri Reykvíkinga um $1 \%$. Algengi blindu er $0,6 \%$ og 5 ára nýgengi $0,4 \%$. Pegar tekið er tillit til mismunar í skilgreiningum sjóntaps og augnsjúkdóma milli rannsókna eru niðurstöður Reykjavíkuraugnrannsóknarinnar svipaðar og sjá má í evrópskum, ${ }^{8}$ bandarískum ${ }^{6,22,23}$ og áströlskum ${ }^{7,24,25}$ rannsóknum á hvítum miðaldra og eldri einstaklingum. Pegar Reykjavíkuraugnrannsóknin hófst árið 1996 var algengi blindu 0,4\% samkvæmt ársyfirliti Sjónstöðvar Íslands og algengi lögblindu (sjónskerpa $\leq 6 / 60$ ) var 0,6\%. Petta er örlítið lægra algengi en í Reykjavíkuraugnrannsókninni, enda vel pekkt að blinduskrár vanmeti að einhverju leyti blindu sökum pess að erfitt getur verið að ná til peirra sem búa á dvalarheimilum fyrir aldraða, lifa við hreyfihömlun eða vitsmunalega hrörnun. Klein og félagar sýndu fram á að peir sem bjuggu á dvalarheimilum fyrir aldraða voru 5 sinnum líklegri til að vera lögblindir en peir sem bjuggu á eigin heimili. ${ }^{22}$ Pátttökuhlutfall í Reykjavíkuraugnrannsókninni var hátt í öllum aldurshópum, nema meðal peirra sem voru 80 ára eða eldri árið 1996. Allir sem kusu að taka ekki pátt í augnskoðuninni sampykktu pó að svara spurningalista og sýndi sig að aðalástæða pess að pátttaka var afpökkuð var sú að margir í elsta aldurshópnum voru of veikir eða hreyfihamlaðir til pess að taka pátt en Reykjavíkuraugnrannsóknin var hátæknirannsókn og ekki mögulegt að ferðast með tækjabúnað milli staða. Pekkt er að 
sjóntap er algengast í pessum aldurshópi og pví er hugsanlegt að Reykjavíkuraugnrannsóknin, sem og aðrar svipaðar rannsóknir, vanmeti að einhverju leyti áhrifin í pessum hóp.

Undanfarna áratugi hefur orðið mikil breyting á helstu orsökum sjóntaps á Íslandi. Til að mynda var gláka orsök lögblindu á Íslandi í helmingi allra tilfella um $1950^{1}$ en vegna aukinnar augnlæknapjónustu, nýrra lyfja og leysimeðferða var gláka aðalorsök minna en $10 \%$ af blindu á níunda og tíunda áratugnum. ${ }^{2,3,26}$ Við grunnskoðun í Reykjavíkuraugnrannsókninni var enginn blindur á báðum augum vegna gláku en 5 manns voru blindir á öðru auganu. Fimm árum síðar hafði enginn orðið fyrir sjónskerðingu eða blindu vegna gláku.

Við væga sjónskerðingu, par sem sjónskerpa var á bilinu 6/18 til <6/12, kom í ljós að skýmyndun á augasteini var orsakavaldurinn í tæplega 40\% tilfella, en enginn reyndist með alvarlegri sjónskerðingu af völdum skýmyndunar. Petta skýrist af pví að enginn biðlisti var fyrir augasteinaskiptaaðgerðir á Íslandi á pessum tíma og staðfestir að gæði og aðgengi að peim var gott. Skýmyndun á augasteini er einnig sjaldgæf orsök alvarlegrar sjónskerðingar og blindu í öðrum vestrænum pjóðfélögum., ${ }^{822-25}$ Pegar skoðuð er sjónskerðing sem eingöngu er bundin við annað augað, má sjá að skýmyndun á augasteini er orsökin í tæplega priðjungi tilfella. Í ljós kom að margir pessara einstaklinga höfðu farið í augasteinaskipti á öðru auganu og fengið svo góða sjón að peir fundu ekki pörf fyrir að fara í aðgerð á hinu, og nú sjónskerta auganu. Petta endurspeglar pá staðreynd að til pess að uppfylla sjónkröfu Umferðarstofu ${ }^{27}$ um akstur bifreiða parf einstaklingur að hafa sjónskerpu sem nemur að minnsta kosti 6/12 pegar horft er með báðum augum í einu og ef einstaklingur notar aðeins annað augað parf sjónskerpa á pví auga að vera að lágmarki 6/12.

Í samræmi við svipaðar rannsóknir ${ }^{8,22-25}$ var aldursbundin augnbotnahrörnun langalgengasta orsök sjóntaps og til að mynda var sjúkdómurinn aðalástæða blindu í 83,4\% tilfella árið 1996. Aldursbundinni augnbotnahrörnun má skipta upp í vota og purra hrörnun. Áður hefur verið sýnt fram á að um priðjungur blindu vegna aldursbundinnar hrörnunar í augnbotnum meðal pátttakenda í Reykjavíkuraugnrannsókninni var vegna votrar hrörnunar og tveir priðju vegna purrar. ${ }^{12,14}$ Undanfarin ár hefur orðið mikil frampróun í meðferð votrar hrörnunar með mótefni gegn vaxtarpætti í æðapeli (anti-VEGF) sem sprautað er í glerhlaup augans. ${ }^{28}$ Háskammtar af C-vítamíni, E-vítamíni, betakarótíni og zinki hægja á sjúkdómi við purra formið. ${ }^{29}$

Latt auga var algengasta orsök sjónskerðingar á öðru auga 1996 og er pað einnig í samræmi við erlendar rannsóknir á miðaldra og eldri einstaklingum. ${ }^{8,24}$ Hægt er að fyrirbyggja stóran hluta sjónskerðingar vegna latra augna með viðeigandi forvörnum og meðferð í barnæsku. Í dag gangast öll börn undir sjónpróf í barnaskoðun við fjögurra ára aldur en pað tíðkaðist ekki pegar pátttakendur í Reykjavíkuraugnrannsókninni voru ungir, enda allir fæddir fyrir 1947 en sjónprófanir barna hófust ekki fyrr en á áttunda áratugnum.

Blindu af völdum sykursýki má í mörgum tilvikum fyrirbyggja með góðri sykurstjórn, reglubundum augnskoðunum og leysimeðferð. Á Íslandi var lögblinda meðal sykursjúkra einstaklinga 2,4\% í upphafi níunda áratugarins en eftir að reglubundnar augnskoðanir og leysiaðgerðir hófust um 1980 féll algengið niður í einungis $0,5 \% .{ }^{30}$ Í samræmi við petta var enginn blindur vegna sykursýki í Reykjavíkuraugnrannsókninni. Sjóntap vegna áverka er einnig sjaldgæft í pessum aldurshópi.

Niðurstöðurnar sýna aukið sjóntap með hækkandi aldri. Stærsti hluti alvarlegs sjóntaps er af völdum aldursbundinnar augnbotnahrörnunar en ský á augasteini veldur oftast vægara sjóntapi. Verulega hefur dregið úr glákublindu á síðustu 50 árum og blinda vegna sykursýki er sjaldgæf. Petta endurspeglar góðan árangur íslenskrar heilbrigðispjónustu og forvarnastarfs.

Pessi rannsókn var styrkt af Sjónverndarsjóði Íslands, japönsku umhverfisstofnuninni, Rannsóknarsjóði Háskóla Íslands og Vísindasjóði Landspítala. 


\section{Heimildir}

1. Björnsson G. Prevalence and causes of blindness in Iceland, with special reference to glaucoma simplex. Am J Ophthalmol 1955; 39: 202-8.

2. Björnsson G. The Borgarnes Eye Study. Nordic Council Arctic Medical Research Report 1980; 26: 34-9.

3. Jonasson F, Thordarson K. Prevalence of ocular disease and blindness in a rural area in the eastern region of Iceland during 1980 through1984. Acta Ophthalmol Supp 1987; 182: 40-3.

4. Organisation for Economic Co-operation and Develop ment. 2012; oecd.org/iceland/Briefing NoteICELAND 2012.pdf - nóvember 2012.

5. Hagstofa Íslands 2012. hagstofa.is/Hagtolur/Mannfjoldinóvember 2012.

6. Klein R, Klein BE, Linton KL, De Mets DL. The Beaver Dam Eye Study: Visual acuity. Ophthalmology 1991; 98 1310-5.

7. Attebo K, Mitchell P, Smith W. Visual acuity and the causes of visual loss in Australia. The Blue Mountains Eye Study. Ophthalmology 1996; 103: 357-64.

8. Buch $\mathrm{H}$, Vinding $\mathrm{T}$, La Cour M, Nielsen NV. The prevalence and causes of bilateral and unilateral blindness in an elderly urban Danish population. The Copenhagen City Eye Study. Acta Ophthalmol Scand 2001; 79: 441-9.

9. Ivers RQ, Cumming RG, Mitchell P, Attebo K. Visual impairment and falls in older adults: the Blue Mountains Eye Study. J Am Geriatr Soc 1998; 46: 58-64

10. Javitt JC, Zhouz, Wilke RJ. Association between vision loss and higher medical care costs in Medicare beneficiaries. Ophthalmology 2007; 144: 238-45.

11. World Health Organization. International statistica classification of diseases and related health problems 10th revision (ICD-10) Version for 2010. who.int/classifications/icd/en - nóvember 2012.

12. Gunnlaugsdottir E, Arnarsson A, Jonasson F. Prevalence and causes of visual impairment and blindness in Icelanders aged 50 years and older: the Reykjavik Eye Study. Acta Ophthalmol 2008; 86: 778-85.
13. Gunnlaugsdottir E, Arnarsson A, Jonasson F. Five-year incidence of visual impairment and blindness in olde Icelanders: the Reykjavik Eye Study. Acta Ophthalmo 2010; 88; 358-66.

14. Jonasson F, Arnarsson A, Sasaki H, Peto T, Sasaki K, Bird AC. The prevalence of age-related maculopathy in Iceland: Reykjavik Eye Study. Arch Ophthalmol 2003; 121 379-85.

15. Jonasson F, Arnarsson A, Peto T, Sasaki H, Sasaki K, Bird AC. 5-year incidence of age-related maculopathy in the Reykjavik Eye Study. Ophthalmology 2005; 112: 132-8.

16. Jonasson F, Damji KF, Arnarsson A, Sverrisson T, Wang $\mathrm{L}$, Sasaki H, et al. Prevalence of open-angle glaucoma in Iceland: Reykjavik Eye Study. Eye (Lond) 2003; 17: 747-53.

17. Arnarsson Á, Jónasson F, Katoh N, Sasaki H, Jónsson V, Kojima M, et al. Áhættupættir skýmyndunar í berk og kjarna augasteins Reykvíkinga 50 ára og eldri. Reykjavíkuraugnrannsóknin. Læknablaðið 2002; 88: 727 31.

18. Katoh $\mathrm{N}$, Jonasson $\mathrm{F}$, Sasaki H, Kojima M, Ono $\mathrm{M}$ Takahashi N, et al. Reykjavik Eye Study Group. Cortical lens opacification in Iceland. Risk factor analysisReykjavik Eye Study. Acta Ophthalmol Scand 2001; 79: 154-9.

19. Gudmundsdottir E, Jonasson F, Jonsson V, Stefánsson E, Sasaki H, Sasaki K. "With the rule" astigmatism is not the rule in the elderly. Reykjavik Eye Study: a population based study of refraction and visual acuity in citizens of Reykjavik 50 years and older. Iceland-Japan Co-Working Study Groups. Acta Ophthalmol Scand 2000; 78: 642-6.

20. Gudmundsdottir E, Arnarsson A, Jonasson F. Five-yea refractive changes in an adult population: Reykjavik Eye Study. Ophthalmology 2005; 112: 672-7.

21. Olsen T, Arnarsson A, Sasaki H, Sasaki K, Jonasson F. On the ocular refractive components: the Reykjavik Eye Study. Acta Ophthalmol Scand 2007; 85: 361-6.
22. Klein R, Wang $\mathrm{Q}$, Klein BE, Moss SE, Meuer SM. The relationship of age-related maculopathy, cataract, and glaucoma to visual acuity. Invest Ophthalmol Vis Sci 1995; 36: 182-91.

23. Munoz B, West SK, Rubin GS, Schein OD, Quigley HA, Bressler SB, et al. Causes of blindness and visual impairment in a population of older Americans: The Salisbury Eye Evaluation Study. Arch Ophthalmol 2000; 118: 819-25.

24. Wang JJ, Foran S, Mitchell P. Age-specific prevalence and causes of bilateral and unilateral visual impairment in older Australians: the Blue Mountains Eye Study. Clin Experiment Ophthalmol 2000; 28: 268-73.

25. Foran S, Mitchell P, Wang JJ. Five-year change in visual acuity and incidence of visual impairment: the Blue Mountains Eye Study. Ophthalmology 2003; 110: 41-50.

26. Sverrisson T. Visual impairment in patients with chronic open angle glaucoma. Acta Ophthalmol 1990: 68 (suppl 195): 71-3.

27. Umferðarstofa. Reglugerð um ökuskírteini nr. 830/2011. III. Viðauki, liður 6.1. Lágmarkskröfur um andlega og líkamlega hæfni til að stjórna vélknúnu ökutæki.

28. Geirsdottir A, Jonsson O, Thorisdottir S, Helgadottir G, Jonasson F, Stefansson E, et al. Population-based incidence of exudative age-related degeneration and ranibizumab treatment load. Br J Ophthalmol 2012; 96: 444-7.

29. Age-related eye disease study research group. Randomized placebo controlled clinical trial of high dose supplementation with vitamin C, E, betacarotin and zinc for age related macular degeneration and vision loss. AREDs Report no. 8. Arch Ophthalmol 2001; 119: 1417-36.

30. Stefánsson $\mathrm{E}$, Bek T, Porta M, Larsen N, Kristinsson JK, Agardh E. Screening and prevention of diabetic blindness. Acta Ophthalmol Scand 2000; 78: 374-85.

ENGLISH SUMMARY

Visual impairment and blindness in Icelanders aged 50 years and older - The Reykjavík Eye Study

Gunnlaugsdóttir E, Arnarsson AM, Jónasson F

Introduction: The purpose of this study was to examine the causespecific prevalence and 5-year incidence of visual impairment and blindness among middle-aged and older citizens of Reykjavík.

Material and methods: A random sample of 1045 persons aged 50 years or older underwent a detailed eye examination in 1996 and 846 of the survivors participated in a follow-up examination in 2001. Visual impairment was defined according to World Health Organization definitions as a best-corrected visual acuity of $<6 / 18$ but no worse than $3 / 60$, or visual field of $\geq 5^{\circ}$ and $<10^{\circ}$ around a fixation point in the better eye. Best-corrected visual acuity of $<3 / 60$ in the better eye was defined as blindness. The causes of visual impairment or blindness were determined for all eyes with visual loss.

Results: The prevalence of bilateral visual impairment and blindness was $1.0 \%(95 \% \mathrm{Cl} 0.4-1.6)$ and $0.6 \%(95 \% \mathrm{Cl} 0.1-1.0)$, respectively and the 5-year incidence was $1.1 \%(95 \% \mathrm{Cl} 0.4-1.8)$ and $0.4 \%(95 \% \mathrm{Cl} 0.0-$ $0.8)$, respectively. The prevalence of visual impairment among 60-69 year old participants was $0.6 \%$, but among those aged 80 years or older the prevalence was $7.9 \%$. The major cause of bilateral visual impairment and blindness both at baseline and follow-up was age-related macular degeneration. Cataract accounted for less severe visual loss. The two most common causes of unilateral visual impairment at baseline were amblyopia and cataract. Cataract was the main cause of unilateral visual impairment at 5-year follow-up.

Conclusion: Prevalence and 5-year incidence of both uni- and bilateral visual impairment and blindness increases with age. Age-related macular degeneration was the leading cause of severe visual loss in this population of middle-aged and older Icelanders.

Key words: Age-related macular degeneration, blindness, cataract, incidence, prevalence, visual impairment

Correspondence: Elín Gunnlaugsdóttir elingun@gmail.com

${ }^{1}$ Department of Ophthalmology, Landspitali University Hospital, Reykjavik, Iceland, ${ }^{2}$ Faculty of Medicine, University of Iceland, Reykjavik, ${ }^{3}$ Neuroscience research, University of Akureyri, Akureyri. 